\title{
Environmental Impact of the Choice of Building Materials in the Context of Sustainable Development
}

\author{
Claudiu ACIU*, Daniela Lucia MANEA \\ Faculty of Civil Engineering, Technical University of Cluj-Napoca, 28 Memorandumului Street, 400114, \\ Cluj-Napoca, Romania; \\ * corresponding author: claudiu.aciu@ccm.utcluj.ro
}

Bulletin USAMV series Agriculture 71(2)/2014

Print ISSN 1843-5246; Electronic ISSN 1843-5386

DOI 10.15835/buasvmcn-agr: 10649

\begin{abstract}
The manufacture of building materials and components, the construction, use and demolition of buildings contribute to the generation of environmental effects such as soil, water and air pollution. The paper defines and synthesizes the impact categories that affect the environment, as well as the factors that cause the appearance of impacts, for the choice of optimal ecological building materials. An important problem is finding impact indices that describe the factors affecting the environment, whose value might be quantified. For this, the study was extended to the methods for the evaluation and analysis of the environmental effects of impact factors. The study performed allowed to synthesize the following impact categories taking into consideration the impact factors that occur during the life cycle of materials: natural resources, human health and risk, pollution due to emissions and waste. The impact factors were analyzed from the point of view of the impact level (geographical extension) and the possible magnitude of their value. This article describes a relatively easy method for the choice of the optimal material from a group of materials, taking into calculation the following impact criteria and categories: depletion of natural resources, environmental degradation, toxic substance emissions due to the energy consumed during the production, execution, exploitation and demolition processes, as well as the possibility of reusing waste.
\end{abstract}

Keywords: building materials, environment, pollution, sustainable development

\section{INTRODUCTION}

Industrial sectors, including the building sector, began to acknowledge the impact of their activities on the environment in the 1990s (Haapio and Viitaniemi, 2008). Designers and builders become increasingly sensitive to the wide spectrum of problems that affect the environment, but are confronted with a confusing number of possible actions and solutions.

The manufacture of building materials and components, the construction, use and demolition of buildings contribute to the generation of environmental effects such as soil, water and air pollution (Curwell and Fox, 2002).

In this context, an important stage in the study of ecological materials is impact analysis, which involves the evaluation of environmental effects, i.e. the passage from environmental impact factors to environmental impact proper.
Impact analysis is carried out in three stages:

- classification of impact factors;

- characterization of the effects of impact factors; - evaluation of the weight of environmental impact.

\section{CLASSIFICATION OF IMPACT FACTORS}

A first method for the classification of impact factors was the "critical volume" method, by which impact factors were classified depending on the physical environment in which they are eliminated: air, water and soil.

The classification of impact factors depending on their environmental effects becomes increasingly used. For example, the nitrogen oxides (NOx) eliminated in the air contribute to both the greenhouse effect and acidification.

Table 1 synthesizes the main environmental impacts of a product or process that can be considered, as well as their way of classification. 
Tab. 1. Categories of environmental impact (Apostol and Ciucaşu, 2000)

\begin{tabular}{|c|c|c|c|}
\hline Impact factors & Impact & Consequences & $\begin{array}{c}\text { Area/ } \\
\text { Impact } \\
\text { Level }\end{array}$ \\
\hline \multicolumn{4}{|c|}{ Category: Resources } \\
\hline $\begin{array}{l}\text { Energy and mineral } \\
\text { resources exploitation }\end{array}$ & $\begin{array}{l}\text { Reduction of non- } \\
\text { renewable natural } \\
\text { resources } \\
\text { Abiotic depletion }\end{array}$ & $\begin{array}{l}\text { Risk of exhaustion of natural resources. } \\
\text { Degradation of the landscape in the case of } \\
\text { overground mining. } \\
\text { Landslides in the case of underground mining. }\end{array}$ & $\begin{array}{l}\text { Global/ } \\
\text { Major }\end{array}$ \\
\hline Wood exploitation & $\begin{array}{l}\text { Reduction of } \\
\text { renewable natural } \\
\text { resources } \\
\text { Biotic depletion }\end{array}$ & $\begin{array}{l}\text { Destruction of the natural habitat, with negative } \\
\text { consequences on the flora and fauna. } \\
\text { Negative influence on the natural water circuit, } \\
\text { with consequences on the climate and extreme } \\
\text { meteorological phenomena. } \\
\text { Landslides. }\end{array}$ & $\begin{array}{l}\text { Global/ } \\
\text { Major }\end{array}$ \\
\hline Water use & $\begin{array}{l}\text { Reduction of water } \\
\text { resources }\end{array}$ & $\begin{array}{l}\text { Desiccation } \\
\text { Destruction of the natural habitat, with negative } \\
\text { consequences on the flora and fauna }\end{array}$ & $\begin{array}{l}\text { Regional/ } \\
\text { Major }\end{array}$ \\
\hline \multicolumn{4}{|c|}{ Category: Human health and risk } \\
\hline $\begin{array}{l}\mathrm{C}_{6} \mathrm{H}_{6}, \mathrm{C}_{6} \mathrm{H}_{5} \mathrm{Cl}, \mathrm{CFC}, \mathrm{H}_{2} \mathrm{~S} \\
\mathrm{~Pb}, \mathrm{Hg}, \mathrm{CHCl}{ }_{3}, \mathrm{C}_{6} \mathrm{H}_{14} \\
\left(\mathrm{PO}_{4}\right)^{3-}, \mathrm{Zn}, \mathrm{St}, \mathrm{Cu}\end{array}$ & Human toxicity & $\begin{array}{l}\text { The accelerated development of industry in all } \\
\text { fields, including building materials, contributes to } \\
\text { the increase of toxic agents. }\end{array}$ & $\begin{array}{l}\text { Regional/ } \\
\text { potential }\end{array}$ \\
\hline $\begin{array}{l}\mathrm{C}_{6} \mathrm{H}_{6}, \mathrm{C}_{\mathrm{x}} \mathrm{H}_{\mathrm{y}^{\prime}} \mathrm{C}_{2} \mathrm{H}_{2}, \mathrm{CH}_{4^{\prime}} \\
\mathrm{C}_{6} \mathrm{H}_{14}\end{array}$ & Oxidant formation & $\begin{array}{l}\text { Formation of photochemical ozone in the } \\
\text { troposphere (smog) }\end{array}$ & $\begin{array}{l}\text { Regional/ } \\
\text { potential }\end{array}$ \\
\hline Number of cases & Victims & $\begin{array}{l}\text { Undesired events resulting in the loss of human } \\
\text { lives or severe injury }\end{array}$ & $\begin{array}{l}\text { Local/ } \\
\text { potential }\end{array}$ \\
\hline \multicolumn{4}{|c|}{ Category: Pollution and waste } \\
\hline $\mathrm{CO}_{2}, \mathrm{CH}_{4}, \mathrm{~N}_{2} \mathrm{O}, \mathrm{CFC}$ & $\begin{array}{l}\text { Global warming } \\
\text { potential }\end{array}$ & Contribution to the global warming of the earth & $\begin{array}{l}\text { Global/ } \\
\text { potential }\end{array}$ \\
\hline $\mathrm{CFC}_{11}, \mathrm{CCl}_{4}$ & Ozone depletion & $\begin{array}{l}\text { The reduced ozone layer density can no longer } \\
\text { protect the organisms and plants from the noxious } \\
\text { ultraviolet rays of the sun. }\end{array}$ & $\begin{array}{l}\text { Global/ } \\
\text { potential }\end{array}$ \\
\hline $\mathrm{SO}_{2^{\prime}}, \mathrm{NO}, \mathrm{NO}_{x^{\prime}} \mathrm{NH}_{3^{\prime}}, \mathrm{HCl}$ & Acidification & $\begin{array}{l}\text { These factors contribute to a basic substance } \\
\text { depletion of the earth's surface, whose acidity } \\
\text { continuously increases. This process leads to } \\
\text { soil and water degradation, as well as to the } \\
\text { deterioration of ecosystems. }\end{array}$ & $\begin{array}{l}\text { Regional/ } \\
\text { potential }\end{array}$ \\
\hline $\begin{array}{l}\mathrm{PO}_{4}^{3-}, \mathrm{NH}_{4}^{+}, \mathrm{NO}_{2}, \mathrm{NO}_{x} \\
\text { and Chemical Oxygen } \\
\text { Demand }\end{array}$ & Nitrification & $\begin{array}{l}\text { This effect translates into a high oxygen consump- } \\
\text { tion in water and terrestrial environments, due to } \\
\text { high nitrate and phosphate concentrations. The } \\
\text { lack of oxygen leads to the reduction of the aquatic } \\
\text { fauna and soil degradation. }\end{array}$ & $\begin{array}{l}\text { Regional/ } \\
\text { potential }\end{array}$ \\
\hline $\begin{array}{l}\mathrm{C}_{6} \mathrm{H}_{6}, \mathrm{Cd}, \mathrm{C}_{6} \mathrm{H}_{5} \mathrm{Cl}, \mathrm{Pb} \\
\mathrm{Hg}, \mathrm{CHCl}_{3}, \mathrm{Cr}, \mathrm{Zn}\end{array}$ & $\begin{array}{l}\text { Aquatic ecotoxicity } \\
\text { Terrestrial } \\
\text { ecotoxicity }\end{array}$ & $\begin{array}{l}\text { Heavy metal and non-halogenated aromatic } \\
\text { hydrocarbon emissions in water and terrestrial } \\
\text { environments have toxic effects, degrading these } \\
\text { environments. }\end{array}$ & $\begin{array}{l}\text { Regional/ } \\
\text { potential }\end{array}$ \\
\hline$[\mathrm{Bq}]$ & Radiation & Irradiated victims & $\begin{array}{l}\text { Local/ } \\
\text { potential }\end{array}$ \\
\hline$\left[\mathrm{m}^{3}\right]$ & Volume de dechets & Pollution of air, water and soil. & $\begin{array}{l}\text { Regional/ } \\
\text { potential }\end{array}$ \\
\hline
\end{tabular}


The table classifies impact factors depending on:

- geographical extension (global, regional or local);

- categories of effects (resources, human health and risk, pollution due to emissions and waste, discomfort and others);

- size of the value (absolute or potential).

\section{EVALUATION OF THE WEIGHT OF ENVIRONMENTAL IMPACT}

The impact analysis of building materials requires the determination of the value of impact factors that appear along the life cycle of these and the assessment of the weight of the impact of various materials.

\section{Methods for the evaluation of impact fac- tors (Badea et al., 2004)}

\section{Exhaustion of natural resources}

The exhaustion of natural resources can be described by means of three parameters: the consumption of raw materials (M), the contribution to the exhaustion of natural resources (T), and the degree of regeneration of raw materials (R).

The consumption of raw materials (M) is calculated using the relation:

$$
M=\Sigma m_{i}[\mathrm{~kg} / \text { functional unit }]
$$

$m_{i}$ - mass of consumed raw material $i[\mathrm{~kg} /$ functional unit].

The contribution to the exhaustion of natural resources $(\mathrm{T})$ is calculated using the relation:

$$
T=\frac{\sum_{i} m_{i} \times \frac{1}{a_{i}}}{M}\left[\mathrm{an}^{-1}\right]
$$

$T$ - contribution to the exhaustion of natural resources [year ${ }^{-1}$;

$a_{i}$ - abundance of raw material reserves $i$ [year];

$M$ - consumption of raw material $[\mathrm{kg} /$ functional unit].

T ranges between 0 and 1 year $^{-1}$, which corresponds to a null or total contribution of the system to the exhaustion of natural resources. $a_{i}$ is the ratio between the status of reserves and the annual international consumption of raw material i.

The degree of regeneration of raw materials $(\mathrm{R})$ is evaluated starting from the relative time of regeneration of raw materials " $t$ ". This index represents the time of regeneration of raw materials in relation to the biomass taken as a reference for $t=1$. Fossil materials such as coal, oil and natural gas have a regeneration time at least 100,000 times higher compared to that of the biomass, while the regeneration time of uranium is practically infinite.

The degree of regeneration of raw materials $R$ is calculated using the relation:

$$
R=\frac{\sum_{i} m_{i} \times\left(1-\frac{1}{t_{i}}\right)}{M}
$$

$R$ - degree of regeneration of raw materials;

$t_{i}$ - relative time of regeneration of raw materials

in relation to the time of regeneration of the biomass taken as a reference;

$\mathrm{R}$ varies between 0 and 1 , which means a total or null regeneration of the raw materials consumed by the system.

\section{Degradation of the landscape}

It is relatively difficult to develop a method for evaluating the degradation of the landscape. A variant would be the scoring method, by which penalties and bonuses for the rehabilitation of the considered space are attributed.

Thus, four levels of degradation of the landscape are defined:

I - natural systems without any human intervention; II - there is a human influence on the initial flora and fauna, but no cultivated surfaces are present;

III - the majority of the space is cultivated;

IV - urbanization is predominant (highways, buildings, etc).

The passage from a lower to a higher degradation level is materialized by a penalty $(\mathrm{P})$, while the rehabilitation of an area (passage from a higher to a lower degradation level) is rewarded by a bonus (Tab. 2). 
Tab. 2. Application of penalties and bonuses for urbanism areas (Badea et al., 2004)

\begin{tabular}{cccc}
\hline Degradation & Penalties & Rehabilitation & Bounty \\
\hline $\mathrm{I} \rightarrow \mathrm{II}$ & 4 & $\mathrm{II} \rightarrow \mathrm{I}$ & 0,25 \\
\hline $\mathrm{II} \rightarrow \mathrm{III}$ & 3 & $\mathrm{III} \rightarrow \mathrm{II}$ & 0,33 \\
\hline $\mathrm{II} \rightarrow \mathrm{IV}$ & 4 & $\mathrm{IV} \rightarrow \mathrm{II}$ & 0,25 \\
\hline $\mathrm{III} \rightarrow \mathrm{IV}$ & 2 & $\mathrm{IV} \rightarrow \mathrm{III}$ & 0,50 \\
\hline
\end{tabular}

Tab. 3. Impact indices in the CML method (Badea et al., 2004)

\begin{tabular}{ccc}
\hline Categories of impact & Impact indices & Units of measurement \\
\hline Global Warning Potential & $\mathrm{GWP}$ & $\mathrm{Kg} \mathrm{CO}_{2}$ equivalent \\
\hline Ozon Depletion Potential & $\mathrm{ODP}$ & $\mathrm{Kg} \mathrm{CFC}_{11}$ equivalent \\
\hline Nutrification Potential & $\mathrm{NP}$ & $\mathrm{Kg} \mathrm{PO}_{4}$ - equivalent \\
\hline Acidification Potential & $\mathrm{AP}$ & $\mathrm{Kg} \mathrm{SO}_{2}$ equivalent \\
\hline $\begin{array}{c}\text { Photochemical Ozone Creation } \\
\text { Potential }\end{array}$ & $\mathrm{PCOP}$ & $\mathrm{Kg} \mathrm{C}_{2} \mathrm{H}_{4}$ equivalent \\
\hline Human Toxicity & $\mathrm{HT}$ & Relative to human body kilograms \\
\hline $\begin{array}{c}\text { Ecotoxicity aquatic } \\
\text { Ecotoxicity terrestrial }\end{array}$ & $\mathrm{ECA}$ & $\mathrm{m}^{3}$ polluted water \\
$\mathrm{kg}_{\text {polluted soil }}$
\end{tabular}

Penalties are subject to the following rules:

- the higher the degradation, the higher the penalty;

- the closer to the natural state the considered area initially is, the higher the penalty for its degradation.

Impact is calculated using the relation:

$$
\mathrm{I}=\mathrm{S} \cdot \mathrm{P} \cdot \mathrm{d}\left[\mathrm{m}^{2} \cdot \text { year }\right]
$$

$S$ - the occupied surface, in $\left[\mathrm{m}^{2}\right]$;

$P$ - the penalty corresponding to Table 2 ; years.

$d$ - the duration of occupation of the space in

\section{Atmospheric emissions}

This method involves the analysis of the effects of impact factors (e.g.: nitrogen oxides induce the acidification of the atmosphere, which causes acid rain with negative effects on vegetation). For a good quantification, the connection between emission - dose - effect should be analyzed: emission (nitrogen oxides) - dose received by the receptor (vegetation) - effect of this dose on the receptor (effect of the amount of nitrogen oxide on vegetation).

In order to analyze the effect of impact factors, this should be quantifiable.

Table 3 presents the impact indices in the CML method and the measurement units by which these are defined (Ojoawo and Gbadamosi, 2013).

For different gases, GWP is expressed compared to GWP relative to $\mathrm{CO}_{2}$, which means that the instantaneous emission of $1 \mathrm{~kg}$ gas is compared to the emission of $1 \mathrm{~kg}$ carbon dioxide taken as a reference, whose global warming potential is considered equal to the unit.

Table 4 presents the GWP values of the main gases with a greenhouse effect, for the warming periods of 20,100 and 500 years. 
In calculations, the shortest time period is usually considered, i.e. the 20 year period.

The GWP index for a system is determined by adding up the elementary greenhouse effect potentials of all gases in the composition of the gaseous effluent of the system, multiplied by the amount corresponding to each component:

$$
G W P=\sum_{i} m_{i} \times G W P_{i}
$$

$G W P_{i}$ - the greenhouse effect potential of element $\mathrm{i}$

of the gaseous effluent [ $\mathrm{kg} \mathrm{CO}$ equivalent];

$m_{i}$ - the amount of element i [kg/functional unit].

The most widely used acidification indicator is equivalent acidity compared to $\mathrm{SO}_{2}$, determined by the relation (Răducanu et al., 2004):

$$
A P=\sum_{i} m_{i} \times A P_{i}
$$

$A P_{i}$ - the acidification potential of a substance i;

$m_{i}$ - the amount of element $\mathrm{i}[\mathrm{kg} /$ functional unit];

$A P$ - the acidification potential $\left[\mathrm{kg} \mathrm{SO}_{2}\right.$ equivalent/

functional unit].
The AP values of a substance are given in Table 5.

In order to enable the comparison of the results of different studies on the life cycle analysis of materials, the UCPTE model for the production of electricity was created at European Union level (Badea et al., 2004), for which the emission amounts $\mathrm{m}_{\mathrm{i}}$ expressed in $\mathrm{mg} / \mathrm{kWh}$, were established.

\section{ANALYSIS OF THE IMPACT OF BUILDING MATERIALS USING THEIR QUALITATIVE ASSESSMENT}

The analysis involves the choice of the ecologically optimal material of the foundation materials category.

In this analysis, the following scores are established, which express the adequacy of the choice depending on the impact factors of the material: 0 - to avoid; 1 - unrecommended, because of major disadvantages; 2 -recommended, although having some small disadvantages; 3 recommended, ideal.

The best material will be considered the material that accumulates the highest score resulting from the arithmetic mean of the scores given to effects.

Tab. 4. GWP values for the main gases with a greenhouse effect (Apostol and Ciucaşu, 2000)

\begin{tabular}{cccc}
\hline Substance & GWP $_{\mathbf{i}}$ (20 years) & GWP $_{\mathbf{i}}(\mathbf{1 0 0}$ years $)$ & GWP $_{\mathbf{i}}$ (500 years $)$ \\
\hline $\mathrm{CO} 2$ & 1 & 1 & 1 \\
\hline $\mathrm{CH} 4$ & 35 & 11 & 4 \\
\hline $\mathrm{N} 20$ & 260 & 270 & 170 \\
\hline
\end{tabular}

Tab. 5. AP values of some substances (Apostol and Ciucaşu, 2000)

\begin{tabular}{cc}
\hline Substance & $\mathbf{A P}_{\mathbf{i}}$ \\
\hline $\mathrm{SO}_{2}$ & 1,00 \\
\hline $\mathrm{NO}$ & 1,07 \\
\hline $\mathrm{NO}_{2}$ & 0,70 \\
\hline $\mathrm{NO}_{\mathrm{x}}$ & 0,70 \\
\hline $\mathrm{NH}_{3}$ & 1,88 \\
\hline $\mathrm{HCl}$ & 1,88 \\
\hline $\mathrm{HF}$ & 1,60 \\
\hline
\end{tabular}


Tab. 6. Technical data

\begin{tabular}{lccc}
\hline \multirow{2}{*}{ Material } & Density & Thermal Conductivity & Specific Heat \\
\cline { 2 - 4 } & $\mathbf{k g} / \mathbf{m}^{\mathbf{3}}$ & $\mathbf{W} /(\mathbf{m K})$ & $\mathrm{J} / \mathbf{k g K}$ \\
\hline Stone & 2180 & 1,5 & 720 \\
\hline Brick from demolition & 1500 & 0,85 & 840 \\
\hline Concrete & 2400 & 2,2 & 840 \\
\hline
\end{tabular}

Tab. 7. Fundamental data useful from an ecological point of view

\begin{tabular}{lcccc}
\hline \multirow{2}{*}{ Material } & Embodied energy & $\mathbf{C O}_{2 \text { eq }}$ & SO $_{2 \text { eq }}$ & Lifetime \\
\cline { 2 - 5 } & {$[\mathbf{k W h} / \mathbf{k g}]$} & {$[\mathbf{g} / \mathbf{k g}]$} & {$[\mathbf{g} / \mathbf{k g}]$} & {$[$ [year/material] } \\
\hline Stone & 0,36 & 88 & 0,33 & 100 \\
\hline Brick from demolition & 0 & 0 & 0 & 50 \\
\hline Concrete & 0,22 & 132 & 0,46 & 80 \\
\hline
\end{tabular}

Tab. 8. Evaluation of environmental efects along the life cycle

\begin{tabular}{|c|c|c|c|c|c|c|}
\hline \multirow{2}{*}{$\begin{array}{l}\text { Life cycle } \\
\text { stage }\end{array}$} & \multirow[b]{2}{*}{ Impact factors } & \multirow[b]{2}{*}{ Impact } & \multirow{2}{*}{$\begin{array}{c}\text { Unit of } \\
\text { measurement }\end{array}$} & \multicolumn{3}{|c|}{ Material } \\
\hline & & & & Stone & $\begin{array}{l}\text { Brick from } \\
\text { demolition }\end{array}$ & Concrete \\
\hline \multirow{5}{*}{ Raw material } & \multirow{2}{*}{$\begin{array}{l}\text { Consumption of raw } \\
\text { materials }\end{array}$} & \multirow{2}{*}{$\begin{array}{c}\text { Depletion of } \\
\text { natural resources }\end{array}$} & {$[\mathrm{kg}]$} & 2180 & 0 & 2400 \\
\hline & & & {$[\mathrm{kv}]$} & 2 & 3 & 1 \\
\hline & \multirow{2}{*}{ Excavation } & \multirow{2}{*}{$\begin{array}{l}\text { Landscape } \\
\text { degradation }\end{array}$} & Level & II & I & II \\
\hline & & & {$[\mathrm{kv}]$} & 2 & 3 & 2 \\
\hline & \multicolumn{3}{|c|}{ Total assessment [kv] } & 2 & 3 & 1,5 \\
\hline \multirow{7}{*}{ Production } & \multirow{2}{*}{ Embodied energy } & \multirow{2}{*}{$\begin{array}{c}\text { Environmental } \\
\text { degradation }\end{array}$} & {$\left[\mathrm{kWh} / \mathrm{m}^{3}\right]$} & 784,8 & 0 & 528 \\
\hline & & & {$[\mathrm{kv}]$} & 1 & 3 & 2 \\
\hline & \multirow{4}{*}{ Environmental effects } & \multirow{2}{*}{ Greenhouse effect } & $\mathrm{CO}_{2 \mathrm{eq}}\left[\mathrm{g} / \mathrm{m}^{3}\right]$ & 191840 & 0 & 316800 \\
\hline & & & $\mathrm{CO}_{2 \mathrm{eq}}[\mathrm{kv}]$ & 2 & 3 & 1 \\
\hline & & \multirow{2}{*}{ Acidification } & $\mathrm{SO}_{2 \mathrm{eq}}\left[\mathrm{g} / \mathrm{m}^{3}\right]$ & 719,4 & 0 & 1104 \\
\hline & & & $\mathrm{SO}_{2 \mathrm{eq}}[\mathrm{kv}]$ & 2 & 3 & 1 \\
\hline & \multicolumn{3}{|c|}{ Total assessment [kv] } & 1,66 & 3 & 1,33 \\
\hline \multirow{5}{*}{ Construction } & \multirow{2}{*}{ Embodied energy } & \multirow{2}{*}{$\begin{array}{c}\text { Environmental } \\
\text { degradation }\end{array}$} & {$\left[\mathrm{kWh} / \mathrm{m}^{3}\right]$} & 0 & 0 & 0 \\
\hline & & & {$[\mathrm{kv}]$} & 3 & 3 & 3 \\
\hline & \multirow{2}{*}{ Harmful emissions } & \multirow{2}{*}{$\begin{array}{c}\text { Environmental } \\
\text { effects }\end{array}$} & - & 0 & 0 & 0 \\
\hline & & & {$[\mathrm{kv}]$} & 3 & 3 & 3 \\
\hline & \multicolumn{3}{|c|}{ Total assessment [kv] } & 3 & 3 & 3 \\
\hline \multirow{6}{*}{ Operating } & \multirow{2}{*}{$\frac{\text { Maintenance }}{\text { Use }}$} & \multirow{2}{*}{$\begin{array}{c}\text { Environmental } \\
\text { effects }\end{array}$} & {$[\mathrm{kv}]$} & n.s. & n.s. & n.s. \\
\hline & & & {$[\mathrm{kv}]$} & n.s. & n.s. & n.s. \\
\hline & \multirow{2}{*}{ Thermal comfort } & \multirow{2}{*}{ Health effects } & {$[\mathrm{W} /(\mathrm{m} \mathrm{K})]$} & 1,5 & 0,85 & 2,2 \\
\hline & & & {$[\mathrm{kv}]$} & 2 & 3 & 1 \\
\hline & Harmful emissions & $\begin{array}{c}\text { Environmental } \\
\text { effects }\end{array}$ & {$[\mathrm{kv}]$} & n.s. & n.s. & n.s. \\
\hline & \multicolumn{3}{|c|}{ Total assessment [kv] } & 2 & 3 & 1 \\
\hline \multirow{3}{*}{$\begin{array}{l}\text { Demolition / } \\
\text { waste }\end{array}$} & Energy & \multirow{2}{*}{$\begin{array}{c}\text { Environmental } \\
\text { effects }\end{array}$} & {$[\mathrm{kv}]$} & 2 & 3 & 2 \\
\hline & Recycling +/- & & {$[\mathrm{kv}]$} & 2 & 3 & 1 \\
\hline & & l assessment [kv] & & 2 & 3 & 1,5 \\
\hline
\end{tabular}


Tab. 9. Ecological evaluation

\begin{tabular}{lccc}
\hline & Stone & Brick from demolition & Concrete \\
\hline Quality Rating [kv] & 2,13 & 3 & 1,66 \\
\hline Ranking (position) & 2 & 1 & 3 \\
\hline
\end{tabular}

The materials were analyzed during their life cycle, from the raw material to the demolition/ waste stage, assuming that the functional unit was $1 \mathrm{~m}^{3}$. The functional unit provides a means of comparing different materials/ products or designs for a given function (Shrestha et al., 2014).

Scores were given depending on the effect values, so that negative effects received the minimum value.

The sources of the data used are from the literature (Hammond and Jones, 2011; Reardon et al., 2011; Takano et al., 2014).

The technical data of the materials included in the study are presented in Table 6 .

In the present case, the best foundation material from an ecological point of view is brick from demolition.

\section{CONCLUSION}

In the presented analysis, it can be noted that the environmental impact of materials manifests during all life cycle stages.

An important observation is the fact that energy is an important impact factor which, although evidenced only in some of the life cycle stages of materials, is present during their entire life cyle. This is supported by the fact that each of the presented life cycle stages are based on energy used for their manufacture as well as energy due to transportation during and between the different stages. Thus, the embodied energy of materials is a particularly important impact factor, whose effects should be given special attention in the analysis of ecological materials.

Advantages of the method: it is relatively simple, it considers the environmental effects along the entire life cycle of the product, it is practical - it provides the designer with clear and accurate information on the best material from an ecological point of view.

Disadvantages of the method: the qualitative value $\mathrm{kv}$ is subjective, the weight of the studied factors is not taken into consideration; although a practical and useful method in designing, it has the disadvantage that it cannot be applied to new materials available on the market, unstudied materials or materials for which no data regarding their environmental effects are available.

In the study and choice of ecological materials, impact analysis is particularly important, but no methodology is currently unanimously accepted by specialists in the field.

The evaluation of the environmental effects of building materials and the finding of reasonable synthetic indices to express the environmental impact represent an open problem of major importance.

Acknowledgments. This paper was supported by the Post-Doctoral Programme POSDRU/159/ 1.5/S/137516, project co-funded from European Social Fund through the Human Resources Sectorial Operational Program 2007-2013.

\section{REFERENCES}

1. Apostol T, Ciucaşu C (2000). Îndrumar de aplicare a metodelor de evaluare a impactului asupra mediului pe baza analizei ciclului de viaţă. Ed. AGIR, București.

2. Badea A, Apostol T, Dincă C (2004). Evaluarea impactului asupra mediului utilizând analiza ciclului de viaţă. Ed. Politehnica Press, Bucureşti.

3. Curwell S, Fox B (2002). Hazardous building materials. A guide to the selection of environmentally responsible alternatives. Ed. Spon Press, London.

4. Haapio A, Viitaniemi P (2008). A critical review of building environmental assessment tools. Environ Impact Asses 28:469-482.

5. Hammond G, Jones C (2011). Inventory of Carbon \& Energy (ICE). Version 2.0. University of Bath, UK. Available online at www.bath.ac.uk/mech-eng/sert/embodied.

6. Ojoawo SO, Gbadamosi AA (2013). Application of TRACI and CML Modeling Tools in Life Cycle Impact Assessment of Municipal Wastes. J Envir Protect Sci. 4:602-617.

7. Răducanu C, Pătraşcu R, Minciuc E (2004). Bilanţuri termoenergetice. Ed. BREN, Bucureşti.

8. Reardon C, Milne G et al. (2011). Your Home Technical Manual, 4th Edition, Australia's guide to environmentally sustainable homes. Institute for Sustainable Futures, University of Technology. Sydney, Australia. 
9. Shrestha S, Biswas K, Desjarlais A (2014). A protocol for lifetime energy and environmental impact assessment of building insulation materials. Environ Impact Asses 46:25-31.
10. Takano A, Winter S, Hughes M, Linkosalmi L (2014). Comparison of life cycle assessment databases: A case study on building assessment. Build Environ 79:20-30. 